\title{
Managing Trade Promotions in the Context of Market Power
}

\author{
Jack J. Kasulis \\ University of Oklahoma \\ Fred W. Morgan \\ University of Kentucky
}

David E. Griffith

Ouachita Baptist University

James M. Kenderdine

University of Oklahoma

The use of trade promotions as a channel-programming tool has increased substantially in the past decade. In focusing on the tactical implications of trade promotions, some firms appear to have underestimated the tendency of poorly planned trade promotions to interfere with the implementation of a marketing strategy. In this article, the authors examine the complex issue of trade promotion use from both long-term and short-term perspectives. Different trade promotions can produce dissimilar types of channel cooperation, consumer responses, and postpromotion channel member behavior, resulting in differences in distribution-programming preferences between suppliers and retailers. The authors argue that the adjudication of these different preference structures is addressed through the market power of the channel participants. Based on an assessment of these channel relationships, an approach for suggested courses of action is forwarded.

Trade promotions are nonroutine marketing inducements designed to influence channel partner behavior (cf. Blattberg and Neslin 1990; Van Waterschoot and Van den

Journal of the Academy of Marketing Science.

Volume 27, No. 3, pages 320-332.

Copyright ( 1999 by Academy of Marketing Science.
Bulte 1992; Zerrillo and Iacobucci 1995). They are used to encourage channel coordination by directing incentives to expand or maintain distribution, gain merchandising support, and/or affect inventories. Their use has the effect of shifting channel profits among members and/or stimulating selective consumer demand.

Trade promotions have become an increasingly important distribution-programming variable for retailers and suppliers. For example, as a percentage of total promotional expenditures, trade promotions for packaged goods have grown from 38 percent in 1985 to approximately 50 percent in the mid-1990s (Cox Direct 1997; Tenser 1996). For retailers, trade promotions provide needed marketing support and increased contributions to profits. Speer (1994) reports that some retailers operating on slim margins rely on trade promotions for 20 to 40 percent of their net profits. For suppliers, trade promotions are used to support distribution and performance objectives. For example, 70 to 90 percent of grocery items shipped are on deal (Zerrillo and Iacobucci 1995).

Ample evidence shows that trade promotions have underachieved in accomplishing channel objectives. Trade promotions have had little impact on a company's underlying baseline sales volume (cf. Davis, Inman, and McAlister 1992; Ehrenberg, Hammond, and Goodhardt 1994; Lucas 1996), and some say that their long-term implications are likely to be negative (cf. Mela, Gupta, and 
Lehmann 1996; Zerrillo and Iacobucci 1995). Even from a short-term perspective, trade promotions may be suspect. For example, only 10 to 20 percent of grocery promotions are profitable events (Orgel 1996). Moreover, if a supplier is caught in a regular cycle of repetitive trade promotion incentives, retailers become conditioned to expect these inducements. This pattern increases the level of trade promotion programming expected for channel cooperation and makes trade promotions difficult to terminate or even manage (Van Waterschoot and Van den Bulte 1992; Zerrillo and Iacobucci 1995).

In this article, we identify market power as a conceptual basis for the study and development of trade promotion policies and programs. We build on the work of others who also have commented on the difficulties inherent in creating coherent trade promotional programs (cf. Buzzell et al. 1987; DeNitto 1994; Farris and Quelch 1987; "Future Vision" 1994; Jones, K. 1989; Jones, J. 1990; Quelch, Neslin, and Olson 1987; Walters 1989, 1991). First, we discuss the role of trade promotions in marketing strategy. Next, we provide a managerial framework for trade promotions in the context of market power. We conclude with a set of normative propositions for the use of trade promotions within different channel scenarios. Our goal is to provide guidance to both suppliers and retailers in the rationalization of trade promotion programs consistent with their respective market positions in the channel.

\section{THE ROLE OF TRADE PROMOTIONS IN MARKETING STRATEGY}

The fundamental goal of trade promotions is to stimulate retailer behavior that promotes customer demand. Both retailers and suppliers should be interested in the efficient application of trade promotion tools to strategically build image, brand equity, and consumer loyalty (Sinnott 1995). Channel efficiency improves channel competitiveness and strengthens channel partners. Inappropriate trade promotion efforts can be dysfunctional. Careful planning and implementation require an understanding of the role of trade promotions in the context of marketing strategy and the conditions that promote effectiveness.

Trade promotions are usually discussed as part of the sales promotion element of an integrated marketing communications strategy consisting of advertising, personal selling, publicity, and sales promotions (cf. Kotler 1997, Rossiter and Percy 1997). The elements should be designed to work in unison to accomplish objectives with the role of each being dependent on how it makes the greatest contribution to the supplier's marketing strategy. Van Waterschoot and Van de Bulte (1992) provide additional insight by making a distinction between sales promotions (consumer and trade promotions) and the core marketing mix. Sales promotions are supplemental inducements that amplify the firm's product, price, distribution, and communication strategies by complementing these activities on a nonroutine or "as need be" basis to accomplish objectives. Thus, sales promotions should depend on and augment a fundamentally sound marketing mix.

While we acknowledge the close association between trade promotions, consumer promotions, and the marketing mix, we confine our analysis to trade promotions because of the complexity, importance, and underachievement of trade promotions. We contend that trade promotion expenditures should be allocated according to the relative value of a particular supplier to a retailer. The less attractive the supplier is to the retailer (i.e., the weaker it is perceived relative to other suppliers), the greater the need for trade promotions to supplement the supplier's marketing mix to obtain retailer cooperation. Moreover, less attractive suppliers have fewer degrees of freedom in devising distribution programming, and the level of inducement necessary to obtain cooperation tends to increase.

\section{LINKING POWER TO TRADE PROMOTIONAL ACTIVITIES}

The impact of trade promotions differs by the type used and the characteristics of the channel partners. Market power is a construct that provides a framework that helps to match trade promotion options with channel objectives. El-Ansary and Stern (1972) define channel power as follows:

The power of a channel member is its ability to control the decision variables in the marketing strategy of another member in a given channel at a different level of distribution. For this control to qualify as power, it should be different from the influenced member's original level of control over its own marketing strategy. (P. 47)

Using trade promotions to garner shelf space, promotional support, or quantity purchases from the retailer are manifestations of channel power in that the supplier altered the retailer's behavior. Similarly, requiring the supplier to pay slotting allowances for retail shelf space alters supplier behavior. The use of power usually does not mean coercion or contentious behavior but rather enticements, persuasion, association, and so forth to gain the desired outcomes.

The successful exercise of power requires an accurate determination of the limits of power and a successful implementation within these limits. Mutual understanding and acceptance of relative channel member power positions generally minimize conflict and should produce more effective channel activities in the long run (cf. Anderson and Weitz 1992; Ganesan 1993; Scheer and 
FIGURE 1 Characteristics of Channel Relationships

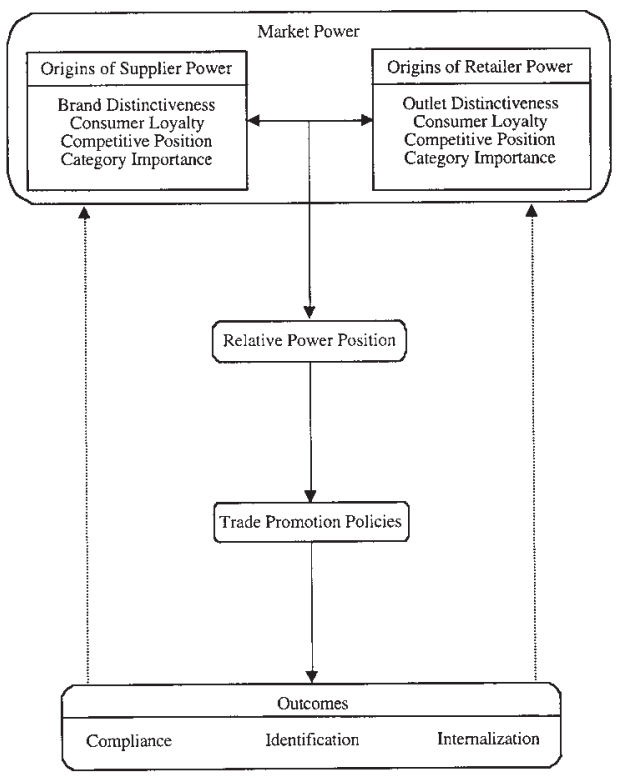

Stern 1992). Beyond current interactions, the outcomes from the use of power affect the future determinants of power. For example, expenditures on advertising aimed at building brand loyalty enhance the supplier's position, while a diversion of money from franchise building to temporary deals such as trade discounts may not.

Figure 1 illustrates the interconnectedness of the origins of channel power, trade promotions, and outcomes. The underlying premise is that a manufacturer's discretion in trade activities is a function of the relative power in its channel relationships, that outcomes differ depending on the trade promotion used, and, accordingly, that they can affect the determinants of power for the future.

\section{Market Power}

Trade promotions can best be understood as part of an overall channel management strategy based on accurate perceptions of both market power and the relative power of the channel participants. We define market power as the strength of a supplier relative to competing suppliers and a retailer relative to competing retailers. On the other hand, relative power is determined by the comparison of market power among trading partners in a channel dyad.

Retailers seek suppliers and suppliers seek retailers with high market power because powerful channel partners can assist them in accomplishing their strategic goals. The strength of a channel member's customer franchise is one characteristic that influences the design of trade promotion programs (Quelch 1989). In other words, retailers and suppliers favor channel relationships and programs with trading partners that have loyal customers. Retailers also favor suppliers that offer a product with a distinctive brand image in product categories of importance for the retailer's strategy and suppliers that can be expected to provide strong distribution, promotional support, and other value-added services. Similarly, suppliers also favor retailers that offer distinctive store images in retail formats of importance for the supplier's strategy and retailers that can be expected to provide strong merchandising, promotional support, and other value-added services.

The attractiveness of a channel member is reflected in the importance of its valued resources and the degree to which they are available from other sources. The extent of the motivational investment in a channel relationship reflects an overall assessment of the rewards and costs of an association (comparison level) against those available from other sources (comparison levels of alternatives) (cf. Anderson and Narus 1984; Dwyer, Schurr, and Oh 1987; Kasulis, Spekman, and Bagozzi 1978; Thibaut and Kelley 1959). Thus, a supplier's attractiveness as a channel partner is derived from the supplier's horizontal strength, that is, its valued resources in relation to other suppliers. Horizontal strength is a reflection of market power. A retailer's attractiveness comes from its horizontal strength, that is, its valued resources in relation to alternative retailers. The comparison of a supplier's horizontal strength vis-à-vis the retailer's horizontal strength determines the balance of power in the dyadic relationship.

For the supplier, power is derived from (1) brand distinctiveness-differentiation of its brand image from those of competitors; (2) consumer loyalty-customer preference for its brand; (3) competitive position-valueadded capabilities such as advertising support, merchandising expertise, and cost-saving programs like efficient consumer response; and (4) category importance-importance of the product category in the retailer's strategy. Similarly, retailer power is derived from (1) outlet distinctiveness-differentiation of the outlet image from those of competitors; (2) consumer loyalty-customer preference for its outlet; (3) competitive position-value-added capabilities such as advertising support, merchandising expertise, and cooperativeness with suppliers; and (4) category importance-importance of the retail format to the supplier's strategy. These horizontal comparisons of scarce resources serve as determinants of a channel member's ability to successfully influence behavior vertically within the channel (Buchanan 1992; Farris and Ailawadi 1992; Keith, Jackson, and Crosby 1990). The weaker the supplier, the larger the inducement needed to gain retailer cooperation. Thus, greater power means more degrees of freedom in the choice of action. 


\section{Outcomes From Exercising Power}

Empirical research shows that the way power is applied affects the character of the outcomes (cf. Anderson and Narus 1984, 1990; Boyle, Dwyer, Robicheaux, and Simpson 1992; Dwyer et al. 1987; Frazier, Gill, and Kale 1989; Frazier and Rody 1991; Frazier and Summers 1984; Keith et al. 1990). In a conceptual article, Frazier and Sheth (1985) emphasize the importance of obtaining both behavior and attitude outcomes from a distribution program. Kasulis and Spekman (1980) offer a philosophically consistent perspective based on Kelman's (1961) three consequences of an influence attempt. They group power outcomes into three categories based on how power is exercised. The outcomes from the use of power were categorized as the following:

1. compliance or short-term behavioral acquiescence,

2. identification or cooperation only within the context of direct association, and

3. internalization or long-term cooperation through the alignment of common goals (behavior and attitude consistency).

Figure 2 defines 13 commonly used trade promotion vehicles and illustrates their connection with the retailer's motivation to participate. The first 4 trade promotions are price inducements designed to increase the economic value for the retailer through increased margins and/or turnover. Trade promotions 5 and 6 are distribution inducements designed to increase the availability of the supplier's offering by temporarily increasing retailer margins. Next are 3 promotional inducements formulated to obtain greater retailer support in building selective demand through retailer merchandising and communications. The 10th and 11th trade promotion inducements seek to motivate individual retailer employees to better "push" the supplier's offering. Finally, the last 2 trade promotions attempt to improve the effectiveness of the push efforts, thereby increasing demand for the supplier's offering.

The trade promotions listed at the top of Figure 2 reflect short-term margin reallocations within the channel. While these promotions may affect a supplier's access to retail shelf space, they may not lead to an increase in consumer preference for either the supplier's brand or the retailer's overall offering. At the bottom of Figure 2 are trade promotions that emphasize building selective demand. These latter trade promotions tend to foster more of a partnering relationship between channel members, resulting in a residual effect beyond the promotion period. Moreover, they develop the supplier's future horizontal strength.

Supplier and retailer goals are frequently at odds. Suppliers prefer distribution programming that increases the selective demand for their product while maintaining supplier margins. Conceptually, trade promotion inducements are designed to compensate the retailer for cooperating to meet this goal. The trade promotions toward the bottom of Figure 2 are better suited for suppliers' objectives. On the other hand, retailers seek the greatest return for their valued shelf space in terms of the margins and turnover of the merchandise that they carry. While the retailer can only speculate about the impact on its profitability from its efforts to promote selective demand for the supplier's product, increased margins are an immediate concrete benefit and therefore tend to be preferred. Thus, the trade promotions toward the top of Figure 2 appear to be better suited for retailer interests.

The orientation of many large retailers is slowly evolving from an individual product perspective toward a category management outlook. A category management perspective focuses on product categories as strategic business units with category goals for sales and profits (cf. Kahn and McAlister 1997; McLaughlin and Hawkes 1994). The category management perspective makes the trade promotion participation decision more complex than a mere SKU analysis. Instead of focusing on performance of an individual product, suppliers attempting to change retailer behavior through trade promotions must fashion programs that improve the overall performance of an entire retail category. Therefore, category management changes, but does not eliminate, the need for and usefulness of trade promotions.

Whether dealing with traditional or category management retailer perspectives, the ability of the supplier to receive a favorable response from the retailer is a function of the supplier's attractiveness (market power), the magnitude of the inducement, and the retailer's marketing strategy. The magnitude of the trade promotion inducement and the supplier's attractiveness as reflected in its brand distinctiveness, consumer loyalty, competitive position, and category importance affect the retailer's trade promotion participation decision. The characteristics of each trade promotion in Figure 2 are explained in greater detail below.

Compliance. Compliance-oriented trade promotions tend to produce temporary behavior change without attitudinal change. These trade promotions can be divided into two groups: binding and nonbinding. Binding compliance-oriented trade promotions obligate retailers to specific behaviors via a carefully delineated contract. Nonbinding promotions offer incentives without the force of a legally binding agreement about the retailer's responsibilities. Street money, free goods, and discounts are nonbinding compliance-oriented trade promotions. At best, they stimulate favorable retailer response for only as long as the promotion period and potentially hurt future sales if consumers stock up on the promoted item. Moreover, if the inducements become excessively routinized, retailers and 
FIGURE 2

Linking Trade Promotions and Outcomes

Trade Promotions

\section{PRICE INDUCEMENTS}

1. Street Money

Lump sum payment to retailers ostensibly to promote the manufacturer's product

2. Free Goods

Extra cases of free goods provided with a purchase at the regular price

3. Discounts

Off invoice for items purchases during a period

4. Billback \& Count-Recount

Retailer bills manufacturer for discount after the units are sold

DISTRIBUTION INDUCEMENTS

5. Inventory Financing

Financing of retailer inventories through extended payment terms

6. Slotting Allowances

Manufacturer payments to obtain retailer shelf space

PROMOTIONAL INDUCEMENTS

7. Calendar Marketing Agreements Agreement with the retailer to have exclusive promotional periods for the manufacturer

8. Display Allowances

Manufacturer payments to defray the costs of retailing displays, usually paid on the basis of cases bought

9. Co-op Advertising and Co-Marketing Programs Supplier-retailer cooperation in the design and payment of consumer promotions, including media tie-ins, direct mail programs, and co-marketed coupons

\section{MOTIVATIONAL INDUCEMENTS}

10. Contests

Prizes given directly to retailer employees for sales performance

11. SPIFFs (Special Promotional Incentive Factory Funds) Direct payments to salespeople of retailer to push manuf.'s product

\section{EFFECTIVENESS INDUCEMENTS}

12. Missionary Selling Supplier's employees work with retailer's customers or salespeople in the promotion of the supplier's product

13. Demonstrations In-store presentations of merchandise for sampling

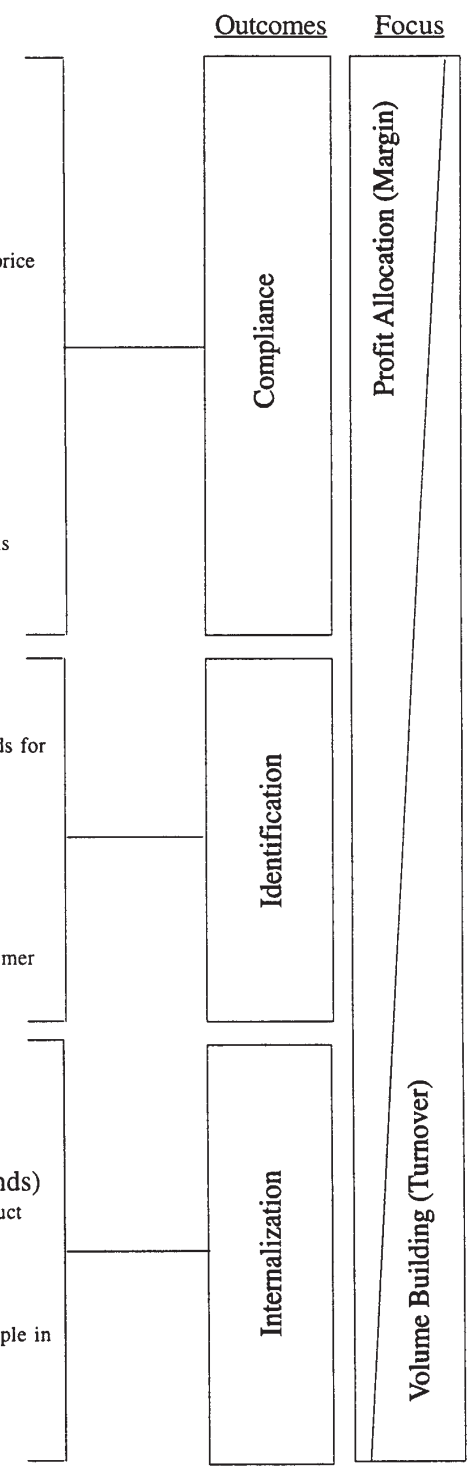

consumers may postpone purchases with the expectation that a deal will be forthcoming.

The retailer presumably will pass all or a substantial portion of the incentives onto consumers as discounts or use the inducements for promotional efforts that stimulate demand. However, in practice, only 35 to 49 percent of manufacturer off-invoice promotion dollars are passed along to consumers by retailers (Nielsen Marketing
Research 1988; Orgel 1996). Moreover, retailers have been known to engage in excessive buying of deal merchandise for sale in nondeal periods (forward buying) and for sale in nondeal territories (diversion). These activities have been shown to increase total channel costs and intrachannel distrust (Buzzell, Quelch, and Salmon 1990). This lack of cooperation increases retailer margins at the expense of cultivating increased sales of the supplier's 
product. Thus, channel profits are reallocated from the supplier to the retailer during the deal period without much benefit for the supplier.

The less attractive (in terms of horizontal strength) the supplier is to the retailer, the less likely the retailer will cooperate, even if it agrees to participate in the trade promotion program. In situations in which behavior uncertainty is high, agency theory prescribes explicit expectations of behavior as a self-selection device to remedy potential opportunism (Bergen, Dutta, and Walker 1992). Because recourse against opportunism is limited, particularly for products with intensive distribution strategies, well-articulated expectations are important as an a priori screening device that identifies likely noncooperative retailers. Moreover, a written contract precisely specifying obligations helps promote the desired channel behavior. Perhaps more important than its legal enforcement mechanism is a contract's delineation of mutual expectations in binding compliance-oriented trade promotions.

Even with appropriate screening efforts, the lack of attitudinal commitment associated with compliance-oriented trade promotions places great importance on monitoring. Recognizing that a supplier cannot account for all contingencies ex ante, transaction cost analysis theory addresses unpredictability in behavior ex post through governance structures (Williamson 1989, 1996). Binding compliance-oriented trade promotions that have active monitoring programs and compensation procedures based on behavior are consistent with this philosophy. Billbacks/count-recounts, inventory financing, and slotting allowances fit this description. Unlike nonbinding trade promotions, these three promotions more precisely specify retailer behavior that potentially expands demand for the supplier's product. For example, while trade discounts may be retained in dealer margins instead of being passed on to the consumer, slotting allowances require increased shelf space that should increase exposure and ultimately demand. Similarly, inventory financing promotes availability and billback/count-recount promotions guarantee consumer discounts by requiring verification of the discounted sales before authorizing the trade promotion payment. Rebate plans for retailers are a variant of a billback/count-recount trade promotion. Although rebate plans are a fairly new concept in distribution programming, Zerrillo and Iacobucci (1995) recommend their use because they shift the cost of monitoring from the supplier to the retailer, thereby reducing the cost of a trade deal as well as increasing cooperation.

Identification. Trade promotions incorporating the properties of identification are those that build on image, reputation, unique abilities, and knowledge of the supplier as perceived by the retailer. Calendar-marketing agreements, display allowances, and cooperative advertis- ing/comarketing programs use the image and reputation of the supplier or require specialized advertising skills that the supplier possesses. These trade promotions require specified behavior that eventually should lead to expanded demand for at least the period of the promotion. These trade promotions can be productively coupled with discounts that reinforce their appeal (cf. Gaski 1986).

Trade promotions that require the recipient to perform additional value-added services tend to have effects that last beyond the promotional period (Zerrillo and Iacobucci 1995). Effectively executed promotional inducements can succeed in building retailer sales, thereby highlighting the advantages of the supplier's product and channel cooperation. Moreover, the supplier's brand equity and the retailer's store equity become more closely associated when the two collaborate on calendar-marketing agreements, displays, and cooperative advertising/comarketing programs. While all supplier products carried by the retailer become a component of the retailer's image, to cooperate through promotional efforts highlights these products within the retailer's image. In a sense, the supplier and retailer act more like partners than buyers and sellers. This identification may carry beyond the promotion period, thus encouraging longer lasting coordination. Zerrillo and Iacobucci (1995) argue that the retailer's selling experience, familiarity, and efficiency with the supplier's product encourage enduring relationships. Customer expectations of product availability at the retailer also promote retailer identification with the supplier.

A high level of monitoring is not necessary when the retailer's behavior is based on the desire to identify with an attractive supplier. In such cases, the supplier's a priori screening has identified a retailer whose cooperation is self-motivated. Part of the popularity of the relationship marketing and category management concepts is that they place greater emphasis on screening channel partners for a cooperative orientation and on seeking "win-win" scenarios. Trade promotions that are associated with identification outcomes also fit a win-win description.

In contrast, if the retailer does not identify with a supplier because of the latter's weak market position, the retailer may accept the promotional allowances without fully committing to its implementation. Murry and Heide (1998) report that noncooperation was common with display allowance programs. Thus, merely offering these trade promotions does not ensure full cooperation-the supplier must have the "clout" to foster retailer commitment. In essence, retailer self-interests are not adequately served by the level of the supplier's attractiveness and the magnitude of the trade promotion inducements. In situations of less attractive suppliers, extra efforts may be necessary. To proceed otherwise reflects an inaccurate assessment of the supplier's market power. Unusually high allowances, sales representatives with strong interpersonal 
attraction, and properly designed performance-based compensation coupled with effective monitoring can improve retailer cooperation (Murry and Heide 1998).

Internalization. Internalization is a term to describe the congruity of retailer-supplier goals. Supplier-sponsored contests and special promotional incentive factory funds (SPIFFs) are two trade promotions that may be associated with internalization. In this presentation, we are not referring to contests and SPIFFs directed to the retail firmthey perform like compliance-oriented price promotions in which there is a temporary reallocation of channel profits. Instead, we are referring to contests, SPIFFs, and other inducements for the retailer's employees offered by the supplier. These promotions reflect a more cooperative arrangement that is associated with internalization because they represent retailer comfort with direct-supplier influence on the retailer's employees. Moreover, when properly designed to nurture an attachment between the supplier and the employees of the retailer, the resulting goodwill can have a lasting effect (Burnett and Moriarty 1998).

Part of the residual effect may be due to the potential training aspects of contests. Research on in-house sales forces has shown that contests can offer residual benefits beyond the incentive period if the sales force develops habits and expertise that improves sales force quality (Meredith and Fried 1977). Similarly, contests can motivate reseller personnel to learn more about the supplier's product, thereby making the retailer's employees more effective and successful in selling the supplier's product (Sirgy 1998). The knowledge, comfort, and success derived from selling the product during the contest period are reinforcing to the relationship and should hold over beyond the promotion period.

Missionary selling and in-store demonstrations also result in a reseller internalization of the supplier's goals. By relinquishing some control of the retailer's selling function to the supplier and allowing the supplier the opportunity for specialized attention, the retailer implicitly endorses the supplier's offerings to consumers. Consumers probably do not make a distinction about whose employee is making the presentation, and even if they did, the in-store presentation implies some level of retailer endorsement. Consequently, the retailer's cooperation through missionary selling and in-store demonstrations psychologically reinforces the notion that its own behavior reflects a beneficial relationship. In attribution theory parlance, the retailer subconsciously attributes the cause of its cooperation (behavior) to the desirability of the relationship (cause). After all, the products that it sells and the people interacting with its customers are an integral part of how the consumer perceives the retailer's image. Therefore, the retailer should not risk damaging its image by permitting in-store demonstrations or presentations for a substandard product.
The supplier also is more likely to receive merchandising cooperation because missionary sales presentations and in-store demonstrations build customer expectations of availability. In this way, the supplier acquires greater psychological legitimacy. In cases in which the product is complicated or the marketing difficult, the supplier also provides expertise for the retailer that helps sell the product. Suppliers with merchandise expertise tend to receive greater support for their programs (Murry and Heide 1998). Thus, the probable consequence of a missionary sales presentation or in-store demonstration is a better alignment of perspectives, resulting in a longer-term cooperative and coordinated relationship.

Contests, SPIFFs, missionary sales, and demonstrations can result in attitude and behavior changes consistent with supplier objectives. These trade promotions offer win-win opportunities for the channel participants. Additional behavioral and psychological reinforcement efforts to further cement the bonding of the relationship and the internalization of common perspectives are also recommended (Frazier and Sheth 1985). Through these actions, long-term channel objectives are furthered.

\section{RATIONALIZING TRADE PROMOTIONS}

With complete freedom of action, suppliers should prefer using trade promotions from the lower end of Figure 2 because they help build selective demand and a closer relationship with the retailer. However, the relative power of the supplier and retailer affect the availability of options. Figure 3 is an overview of four typical supplier-retailer power relationships: dominant supplier, dominant retailer, strong symmetric, and weak symmetric. The greater the power imbalance within the dyad, the greater the latitude of the more powerful member to prescribe trade promotion activities.

\section{Dominant Supplier Situation}

A dominant supplier situation is one in which the supplier holds greater market power relative to its retail partner. As illustrated in Figure 1, a supplier's market power emanates from brand distinctiveness, consumer loyalty, competitive position, and category importance compared to similar retailer attributes. Therefore, the scope of power is specific to the brand/model and line of trade. A large nationwide supplier of an important product category for a small local retailer illustrates the dominant supplier situation. For their stronger brands and models, Trek bicycles holds such a position with locally owned bicycle specialty stores, Procter \& Gamble with independent supermarkets, and Ford with smaller single-outlet car dealerships. Because of its attractive market position, the supplier has 


\section{FIGURE 3 \\ A Typology of Retailer-Supplier Power Relationships and Recommended Trade Promotions}

\begin{tabular}{|c|c|c|}
\hline & Strong Supplier Power & Weak Supplier Power \\
\hline & Dominant Supplier & Weak Synmetric \\
\hline $\begin{array}{l}\text { Weak } \\
\text { Retailer } \\
\text { Power }\end{array}$ & $\begin{array}{l}\text { Important Retail Forms Only } \\
\text { 1. Has Other S-R Relationships } \\
\text { - Coop Advertising/Co-Marketing } \\
\text { 2. Trades Mainly with Small Retailcrs } \\
: \text { Display Allowannes } \\
\text { Coop Advertising/Co-Marketing } \\
\text { : Contests } \\
\text { SPIFFs }\end{array}$ & Billbacks/Count-Recounts \\
\hline & Strong Symmetric & Dominant Retailer \\
\hline $\begin{array}{l}\text { Strong } \\
\text { Retailer } \\
\text { Power }\end{array}$ & $\begin{array}{l}\text { Calendar Marketing Agreements } \\
\text { Display Allowances } \\
\text { Coop Advertising/Co-Marketing } \\
\text { Missionary Selling } \\
\text { Product Demonstrations }\end{array}$ & $\begin{array}{l}\text { Billbacks/Count-Recounts } \\
\text { Slonting Allowances } \\
\text { Inventory Financing }\end{array}$ \\
\hline
\end{tabular}

greater flexibility in determining its marketing programming.

Dominant suppliers build their customer franchises through an effective marketing mix that includes strong emphasis on direct-to-the-consumer communications, such as advertising, loyalty programs, and sampling. Because retailers are inclined to participate in marketing programs with attractive suppliers, the supplier gains little advantage from offering price and distribution inducements (see Figure 2 for specific trade promotions). Trade promotions should be viewed as supplemental to consumer promotions and primarily directed at fostering customer loyalty, which in turn yields greater profits and increased channel attractiveness.

Proposition 1: A supplier in a dominant position should minimize trade promotion activity.

When trade promotions are used, they should be part of a supplier's integrated marketing communications strategy, complementing consumer promotions and advertising, that has the goal of building lasting preferences for its brand. The extent to which a dominant supplier is interested in trade promotions at all is a function of the importance of the retail form to the marketing of the product category. Lines of trade that have lower category impor- tance for a supplier should attract little or no trade promotion activity. For example, Procter \& Gamble should not devise trade promotions targeted to convenience stores for Tide laundry detergent. Its focus should be on more important lines of trade such as supermarkets and discount stores. This saves limited resources for relationships that offer more valued resources such as those found in strong symmetric relationships. For these more important retail forms, occasional cooperative advertising/comarketing programs may be offered to reinforce the relationship while promoting selective demand.

Mainly trading with small retailers. An exception to Proposition 1 is the situation in which the supplier is almost exclusively associated with small independent retailers. Paradoxically, suppliers in this situation appear dominant in their dyadic relationships, yet they should devote attention to these small independent retailers because the supplier is solely dependent on their collective productivity. The supplier does not have the option of allocating scarce resources to more attractive retailers. Essentially, the category importance of the retailers increases because of the supplier's lack of options. We believe that the aggregate impact of these retailers suggests that the best interests of the supplier are to more actively pursue demand-stimulating trade incentives than suggested by Proposition 1, although future research is needed to address this question more definitively.

Under our assumption, both the promotional inducements of display allowances and cooperative advertising/comarketing programs and the trade promotions designed to motivate individual retail employees (contests and SPIFFs) are cost-effective. In most cases, missionary selling and demonstrations are not cost-effective because of the large number of small-volume locations. Improving the effectiveness of these activities might be addressed through supplier-sponsored training programs at regional locations.

Trade promotions offered by the dominant supplier should be well received, and the magnitude of the incentives need not be large due to the retailer's desire to trade with an attractive supplier. Moreover, the particular trade promotions recommended have the added benefit of fostering a cooperative atmosphere between the channel partners. This cooperative atmosphere should continue even after the trade promotion expires. These trade promotions also further strengthen the supplier's market power position by building a stronger customer franchise.

Because of the cost of serving many small retailers, consideration should be given to establishing thresholds of performance. Apparently, Levi-Strauss and Fleming Foods have come to this perspective in their trade relations policies, although not specifically related to trade promotions. Levi-Strauss has imposed minimum annual sales thresholds of $\$ 10,000$ for retailers who wish to carry Levi 
products ("Levi's Letter to Small Stores" 1994). This policy locks out extremely small retailers who are in a weak market position. Fleming Foods has initiated an alternative approach. Fleming changed to activity cost pricing for its services (Orgel 1995). Merchandise is sold at a base price, and additional charges are imposed for services rendered. Analogous threshold considerations should be established in the design of trade promotions, consistent with Robinson-Patman requirements that price differences are allowed if they are based on differences in cost structures.

Other supplier considerations. A supplier strategy of offering an everyday low purchase price (EDLPP) to retailers may be an attractive alternative to heavy trade promotion activity for the dominant supplier. EDLPP prices merchandise to the retailer based on a weighted average of deal and regular prices in proportion to the prior purchases at each price level. It offers the prospect of smoothing the production process and reducing inventory, warehousing, and handling costs (Buzzell et al. 1990). While EDLPP at the retailer to consumer level can lead to lower profits for the retailer, EDLPP offers benefits to both the supplier and retailer (Hoch, Dreze, and Purk 1994). Moreover, already possessing a strong market position, dominant suppliers have modest incentive to divert resources to trade promotions. In addition, switching to EDLPP helps nationally known brands compete more effectively with distributors' brands. These private labels sell primarily on the basis of lower price, and because they are the retailers' products, they are guaranteed shelf space. When national brands move to EDLPP, additional consumer advertising can support them. This has been shown to "protect" them from retailers' labels ("Food Fundamentalism" 1993) as well as offering a consistently better value to consumers.

Procter \& Gamble has moved to a similar strategy. They reduced prices by as much as 25 percent on more than one-half of their products while decreasing trade promotion expenditures (Schiller 1993). Procter \& Gamble introduced value pricing as a win-win option. Its own profitability would improve through lower trade incentive costs and lower standard margins, and retailers also would ultimately benefit through reduced costs. Initially, many retailers thought this was a "win-lose" situation and publicly expressed their anger (DeNitto 1992; Johnson et al. 1992). Over time, the value of the value pricing approach became more widely recognized.

\section{Dominant Retailer Situation}

A dominant retailer situation is one in which the retailer's market power exceeds that of the supplier. A strong national retailer and a small supplier exemplify the dominant retailer scenario. Safeway Supermarkets trading with regional dairies, Target Stores with local plant nurseries, and Toys "R" Us with a small board game manufacturer are examples of this situation.

Suppliers in this situation have limited flexibility in their trade promotion strategy. Dominant retailers are likely to be more restrictive in their shelf space allocations and overall support of the subordinate supplier than with more attractive suppliers. In these cases, the retailer is in a powerful bargaining position to request concessions from the supplier that increase the retailer's direct product profitability.

Proposition 2: A retailer in a dominant position should favor supplier trade promotions that shift channel profit from the supplier to the retailer.

Subordinate suppliers are caught in a difficult paradox. Their weak relative power position suggests a need to build a stronger consumer franchise through advertising, consumer promotions, and other demand-stimulating activities (Agrawal 1996), yet these resources need to be diverted to trade promotions that gain retailer participation. This produces a negative relationship between the optimal level of advertising and trade promotions for the supplier (Neslin, Powell, and Stone 1995). Promotional incentives would be desirable, but retailers are less responsive to such supplier programs because of past accomplishments visà-vis competition and the adjustment costs of realigning the distribution system's inventories. This is particularly true if the supplier's product is an insignificant element in the retailer's product mix and corresponding strategy. Moreover, dominant retailers probably would tend to resist direct incentives designed to motivate their employees (contests and SPIFFs) so as to minimize compromising retailer objectives. Similarly, they would tend to reject offers of missionary selling and demonstrations, preferring offers from more attractive suppliers.

Incentives that immediately improve the profitability of the line (inventory financing, billbacks/count-recounts, slotting allowances) usually are necessary in addition to strong supplier advertising and consumer promotional efforts. Thus, suppliers are trapped into behavior-inducing, but not attitude-enhancing, promotions. Anderson and Narus (1990) capture the situation:

Relative dependence is found to be a significant antecedent of influence in the working partnership, which suggests that a less dependent firm can enact successfully the various influence strategies.... A more dependent firm, in contrast, should seek ways to add value (or reduce cost) to the exchange for the partner firm at a relatively small cost to itself. (P. 56)

Moreover, suppliers with particularly weak horizontal strength may not receive a positive response from dominant retailers even with above-average trade inducements. Ultimately, these suppliers may be forced into becoming 
providers of products for private brands, thereby shifting promotional responsibilities to the retailer.

Increasing interdependency. Another alternative for the subservient supplier is to attempt to alter the power equation. Automatic reordering programs, immediate electronic transfer of sales data to suppliers, and supplierdeveloped category management programs are three illustrations of supplier attempts to improve its competitive position and lessen trade promotion demands by retailers. These improved channel services add value or reduce retailer costs, thereby increasing the supplier's horizontal strength. Consequently, the supplier becomes more attractive.

Golden Cat is a good example of a supplier that has altered its power position through information technology rather than distribution programming. Golden Cat, marketers of Kitty Litter Maxx and Tidy Cat brands of cat litter, is a single-category seller in competition with wellknown Fortune 500 packaged goods marketers. Their key to success is based on providing an effective category management program. Golden Cat has devoted considerable resources to efficient consumer response (ECR) programs in recent years (Liesse 1994). By exchanging sales data with key retailers, Golden Cat can track daily sales on a store-by-store basis, thereby allowing it to quickly replenish stock based on how consumers respond to retailers' instore promotions. Retailers enhance their merchandise turnover by receiving just-in-time deliveries rather than storing cat litter. In addition, Golden Cat has demonstrated that fewer SKUs would allow retailers to improve profits by selling higher margin brands (Liesse 1994).

\section{Strong Symmetric Situation}

A strong symmetric situation is one in which the supplier and the retailer are strong and equal in market attractiveness. A strong national retail chain and a strong supplier illustrate a strong symmetric relationship. For their stronger brands and models, Procter \& Gamble selling to Safeway, Mattel to Toys "R" Us, and Sony to Target Stores are examples of this type of situation. Here, both the supplier and the retailer recognize each other's countervailing power. Thus, attempts at profit shifting through trade promotion activity are not likely to be productive. Perhaps more important, the mutual attractiveness encourages finding mutually beneficial cooperative ventures.

Proposition 3: Channel partners in strong symmetric relationships should favor trade promotions that strengthen channel relationships by promoting cooperation in mutually beneficial activities.

Mutually beneficial trade promotions are those that promote relationships and enhance consumer demand.
These include display allowances, cooperative advertising/comarketing programs, missionary selling, and product demonstrations. When more than one strong supplier exists, such as Coke and Pepsi, calendar-marketing agreements are useful because they "manage" the competitive process by limiting trade and consumer promotions to one company per calendar period. Because many large retailers prohibit direct employee incentive programs to minimize outside influence that may compromise retailer objectives, contests and SPIFFs are less preferred options.

\section{Weak Symmetric Situation}

A weak symmetric situation is one in which neither the supplier nor the retailer is strong in market attractiveness. A small local retailer (such as a local independent supermarket) and a small supplier (such as a local jam and jelly producer) illustrate a weak symmetric situation. Neither channel member has much freedom in determining its marketing programming when dealing with more dominant partners, but there are opportunities with each other.

Proposition 4: Channel partners in weak symmetric relationships should favor price-oriented trade promotions in an attempt to gain or hold market share.

Placed in a survival mode, channel partners in weak symmetric relationships are likely to use trade promotions that result in temporary price cuts that are passed along to the consumer, giving both supplier and retailer a temporary price advantage over their more dominant rivals. Billback/count-recount trade promotions are appropriate, while nonbinding compliance-oriented price promotions should be resisted. Their common vested interests should negate a need for distribution enhancing trade promotions (slotting allowances and inventory financing).

\section{IMPLICATIONS}

The typology presented in Figure 3 and the related research propositions should be tested empirically. Based on our extrapolations from the market power and trade promotion literatures, we believe the propositions possess face validity and will withstand empirical scrutiny. The data collection will be challenging for academic researchers because of the proprietary nature of the needed information. Expenditures by trade promotion category by channel partner characteristics by product/category are not publicly available. The competitive value of this information minimizes the likelihood that companies would supply it, at least in undisguised format. This highlights the need for cooperative research efforts between academic researchers and practitioners on this topic. 
Fundamental to implementing the proposed trade promotion framework is an accurate assessment of supplier and retailer power. We identified brand/outlet distinctiveness, consumer loyalty, competitive position, and category importance as four origins of market power that are of relevance in selecting trade promotion alternatives. Research should examine the appropriateness of these four origins, the interrelationship among the origins, and the effect on trade promotion policy. Issues such as potential thresholds, compensatory effects, and synergism warrant investigation.

We further argue that trade promotion activity can affect future relations with channel partners and can affect future channel power. The posited outcomes of trade promotion activity need empirical investigation. For example, we postulate that contests promote retail employee bonding with the supplier. Does this typically occur, does it require certain types of contests, does the outcome hold for only particular types of employees, or does the employee revert to previous behavior once the contest expires? In addition, our presentation excludes street money, free goods, and discounts as undesirable trade promotion options unless tied to a multielement distributionprogramming package in which performance requirements can be monitored. It would be worthwhile to explore whether there are instances in which street money, free goods, and discounts can stand alone as acceptable options.

Another important test of these propositions is to assess their applicability across several industries. The research question is whether product- or industry-specific characteristics restrict the generalizability of this research. For example, does the model hold for both low and high technology industries? Does the model hold equally well in mature industries versus those that are less mature? We believe that relative power within these supplier-retailer dyads will account for these interindustry differences, but this needs to be studied.

On a more microlevel, the predictive efficacy of the research typology should be assessed for products of varying degrees of newness and brand prominence. For example, within the supplier-retailer dyads in Figure 3, would the same trade promotion mix be used for new brands as for existing brands? Would equivalently powerful suppliers, one using a family-branding strategy and the other implementing an individual-brand strategy, use approximately the same trade promotional combinations? In other words, would brand synergies result in different trade promotion mixes?

A related question is how a supplier or retailer should respond if a competitor implements a trade promotion program that is inconsistent with our typology and propositions. Would a radical departure from our recommendations be required to counter this competitor's actions, or would these actions be ultimately self-defeating? How many different mixes of trade promotion programs and magnitudes can be successful within similar seller-retailer dyads?

The relationship between retailer assortments and trade promotions should also be examined. Do supplier trade promotions influence retailer assortments in the long run? We expect to see such influence when strong suppliers are dealing with weak retailers, but we are uncertain if powerful retailers would alter assortments to accommodate certain trade promotions.

When retailers make strategic line-of-trade decisions, the role of trade promotions will be affected with regard to some products. For example, do trade promotional programs for laundry detergent change when Wal-Mart expands from traditional general merchandise discount stores to superstores that include a full-line supermarket? In the traditional Wal-Mart discount store, laundry detergents represent a nonessential product category and, as such, are not integral to the image and success of the general-merchandise discount store operation. By contrast, in Wal-Mart superstores, consumers expect to find laundry detergents and other products typically found in traditional supermarkets. Thus, the market power of suppliers such as Procter \& Gamble may increase vis-à-vis Wal-Mart through increased product category importance associated with Wal-Mart's line-of-trade decision.

Finally, two theoretical issues ought to be studied in greater detail. First, we have proposed that trade promotions influence future power of suppliers and retailers via feedback links. The existence of these links needs to be established empirically. A longitudinal study is needed to confirm the appealing perspective that power accumulates over time.

Second, the model, for purposes of presentation, has been reduced to a two-by-two (high and low power) matrix. Power is likely to be a continuous variable, at least for some ranges. Additional research is needed to establish ranges of power and to determine if power is relatively seamless or if power thresholds are recognizable.

\section{SUMMARY}

Channel coordination involves the complex interaction of economic, social, and governance issues. By recognizing these issues, trade promotions can be effective in finetuning relations and overcoming hurdles not fully addressed by ongoing product, price, distribution, and communication strategies. Understanding that the origins of market power are based on valued scarce resources clarifies the degrees of freedom a supplier has in dealing with its channel partners. More relative power gives a firm greater discretion in its distribution programming. 
Trade promotions can reallocate channel profits, increase selective demand, and affect the supplier's future market power by affecting its consumer franchise. Therefore, suppliers should examine the long-term implications of trade promotions in addition to their short-term results and judiciously select the appropriate trade promotions for their strategic position.

We believe that much of the increase in trade promotions over the last decade did not support supplier strategies. The growth in trade promotions was an attempt to obtain a "quick fix," and their misuse created serious long-term strategic problems for many suppliers. We argue that one reason strategic problems result from the misuse of trade promotions is that managers lack a theoretical framework for trade promotion programming. This framework should highlight the implementation role of trade promotions and provide a perspective for selecting specific trade promotion practices for particular competitive situations.

We have described the trade promotion situation in detail and have provided a framework that offers guidelines for choosing the most appropriate types of promotions. This framework, while requiring empirical testing through further research, is consistent with the extant literature on distribution channels and market power. We hope that it will motivate both suppliers and retailers to think about important issues relating to inappropriate use of trade promotions and the consequent erosion of competitive position. Proper implementation of trade promotions using this framework has the potential to enhance a firm's competitive advantage.

\section{REFERENCES}

Agrawal, Deepak. 1996. "Effect of Brand Loyalty on Advertising and Trade Promotions: Theory and Empirical Evidence." Marketing Science 15 (Winter): 86-108.

Anderson, Erin and Barton Weitz. 1992. "The Use of Pledges to Build and Sustain Commitment in Distribution Channels." Journal of Marketing Research 29 (February): 18-34.

Anderson, James C. and James A. Narus. 1984. "A Model of the Distributor's Perspective of Distributor-Manufacturer Working Relationships.” Journal of Marketing 48 (Fall): 62-74.

— and 1990. "A Model of Distributor Firm and Manufacturer Firm Working Partnerships.” Journal of Marketing 54 (January): $42-58$.

Bergen, Mark, Shantanu Dutta, and Orville C. Walker, Jr. 1992. "Agency Relationships in Marketing: A Review of the Implications and Applications of Agency and Related Theories." Journal of Marketing 56 (July): 1-24.

Blattberg, Robert C. and Scott A. Neslin. 1990. Sales Promotion: Concepts, Methods and Strategies. Englewood Cliffs, NJ: Prentice Hall.

Boyle, Brett, F. Robert Dwyer, Robert A. Robicheaux, and James T. Simpson. 1992. "Influence Strategies in Marketing Channels: Measures and Uses in Different Relationship Structures." Journal of Marketing Research 29 (Fall): 462-473.

Buchanan, Lauranne. 1992. "Vertical Trade Relationships: The Role of Dependence and Symmetry in Attaining Organizational Goals." Journal of Marketing Research 29 (February): 65-75.

Burnett, John and Sandra Moriarty. 1998. Introduction to Marketing Communications. Englewood Cliffs, NJ: Prentice Hall.
Buzzell, Robert D., Marci Dew, Therese Falherty, Jay Jaikumar, John Quelch, and Walter Salmon. 1987. "Trade Promotion and Food Distribution Cost." Food Marketing Foundation working paper.

_ John A. Quelch, and Walter J. Salmon, Jr. 1990. "The Costly Bargain of Trade Promotion." Harvard Business Review 68 (MarchApril): 141-149.

Cox Direct. 1997. Navigate the Promotional Universe (19th Annual Survey of Promotional Practices). Largo, FL.

Davis, Scott, Jeffrey Inman, and Leigh McAlister. 1992. "Promotion Has a Negative Effect on Brand Evaluations-Or Does It? Additional Disconfirming Evidence." Journal of Marketing Research 29 (February): $143-148$.

DeNitto, Emily. 1992. "Super Value Hikes Charge on P \& G Items." Supermarket News 42 (June 22): $1+$.

2. 1994. "Brand Building Carries the Day; Quick-Fix, PriceDriven Promotions Lag Behind Futurist Approach." Advertising Age, March 21, p. S4+.

Dwyer, F. Robert, Paul H. Schurr, and Sejo Oh. 1987. "Developing Buyer-Seller Relationships.” Journal of Marketing 51 (April): 11-27.

Ehrenberg, A.S.C., K. Hammond, and G. J. Goodhardt. 1994. "The After Effects of Price Related Consumer Promotions." Journal of Advertising Research 34 (July/August): 11-21.

El-Ansary, Adel I. and Louis W. Stern. 1972. "Power Measurement in the Distribution Channel." Journal of Marketing Research 9 (February): 47-52.

Farris, Paul W. and Kusum L. Ailawadi. 1992. "Retail Power: Monster or Mouse." Journal of Retailing 68 (Winter): 351-369.

_ and John A. Quelch. 1987. "In Defense of Price Promotion." Sloan Management Review 27 (Fall): 63-69.

"Food Fundamentalism." 1993. The Economist, December 4, pp. 11-12.

Frazier, Gary L. and Raymond C. Rody. 1991. "The Use of Influence Strategies in Interfirm Relationships in Industrial Product Channels." Journal of Marketing 55 (Winter): 52-69.

_ and Jagdish N. Sheth. 1985. "An Attitude-Behavior Framework for Distribution Channel Management." Journal of Marketing 49 (July): 38-48.

— and John O. Summers. 1984. "Interfirm Influence Strategies and Their Application Within Distribution Channels." Journal of Marketing 48 (Summer): 43-55.

_ James D. Gill, and Sudhir H. Kale. 1989. "Dealer Dependence Levels and Reciprocal Actions in a Channel of Distribution in a Developing Country." Journal of Marketing 53 (January): 50-69.

"Future Vision: Food Industry Leaders Struggle to Find Ways to Balance New Technology, Competitive Threats, and Revolutionary Change in the Distribution System With the Traditional Need to Provide HighProfile Customer Service.” 1994. Grocery Marketing 60 (March): 6-17.

Ganesan, Shankar. 1993. "Negotiation Strategies and the Nature of Channel Relationships." Journal of Marketing Research 30 (Spring): 183-203.

Gaski, John F. 1986. "Interrelations Among a Channel Entity's Power Sources: Impact of the Exercise of Reward and Coercion on Expert, Referent, and Legitimate Power Sources." Journal of Marketing Research 23 (February): 62-77.

Hoch, Stephen J., Xavier Dreze, and Mary E. Purk. 1994. "EDLP, Hi-Lo, and Margin Arithmetic." Journal of Marketing 58 (Fall): 16-27.

Johnson, Bradley, Riccardo A. Davis, Christy Fisher, Cleveland Horton, Scott Hume, and Jennifer Lawrence. 1992. "Retailers Accepting P \& G Low Pricing." Advertising Age, June 22, pp. 36+.

Jones, John P. 1990. "The Double Jeopardy of Sales Promotions." Harvard Business Review 68 (September-October): 145-152.

Jones, Keith. 1989. "Brand Hostaging and How to Deal with It." In Measuring and Evaluating Sales Promotions From the Manufacturer and Retailer Perspectives. Eds. Robert W. Shoemaker, Kenneth G. Hardy, and Herbert F. McKenzie. Cambridge, MA: Marketing Science Institute, 14-16.

Kahn, Barbara E. and Leigh McAlister. 1997. Grocery Revolution: The New Focus on the Consumer. Reading MA: Addison-Wesley.

Kasulis, Jack J. and Robert E. Spekman. 1980. "A Framework for the Use of Power." European Journal of Marketing 14 (4): 180-191.

_ _ and Richard P. Bagozzi. 1978. "A Taxonomy of Channel Influence: A Theoretical-Operational Framework." In Future Di- 
rections for Marketing. Eds. George Fisk, Johan Arndt, and Kjell Gronhaug. Cambridge MA: Marketing Science Institute, 162-184.

Keith, Janet E., Donald W. Jackson, Jr., and Lawrence A. Crosby. 1990. "Effects of Alternative Types of Influence Strategies Under Different Channel Dependence Structures." Journal of Marketing 54 (July): 30-41.

Kelman, H. C. 1961. "Processes of Opinion Change." Public Opinion Quarterly 25: 57-78.

Kotler, Philip. 1997. Marketing Management: Analysis, Planning, Implementation, and Control. Upper Saddle River, NJ: Prentice Hall.

"Levi's Letter to Small Stores." 1994. Daily News Record, July 20, p. 8.

Liesse, Julie. 1994. "The Nitty-Gritty of ECR Systems: How One Company Makes It Pay." Advertising Age, May 2, pp. 1S+.

Lucas, Anthony. 1996. "In-Store Trade Promotions-Profits or Loss?" Journal of Consumer Marketing 13 (Spring): 48-50.

McLaughlin, Edward W. and Gerard F. Hawkes. 1994. Category Management: Current Status and Future Outlook. Food Industry Management Program. Ithaca, NY: Cornell University.

Mela, Carl F., Sunil Gupta, and Donald R. Lehmann. 1996. "The Longterm Impact of Promotion and Advertising on Consumer Brand Choice." Working Paper, 96-127, Marketing Science Institute, Boston.

Meredith, George and Robert P. Fried. 1977. Incentives in Marketing. Union, NJ: National Premium Sales Executives.

Murry, John P. and Jan B. Heide. 1998. "Managing Promotion Program Participation Within Manufacturer-Retailer Relationships." Journal of Marketing 62 (January): 58-58.

Neslin, Scott, Stephen G. Powell, and Linda Schneider Stone. 1995. "The Effects of Retailer and Consumer Response on Optimal Advertising and Trade Promotion Strategies.” Management Science 41 (May): 749-766.

Nielsen Marketing Research. 1988. First Annual Survey of Manufacturer Trade Promotion Practices. New York: A. C. Nielsen.

Orgel, David. 1995. "Partnering Keys NAWGA Event." Supermarket News 45 (March 20): 12-14.

. 1996. "Study Urges Trade Promotion Changes." Supermarket News 46 (September 23): 4-5.

Quelch, John A. 1989. "Influences on Sales Promotion Design.” In Sales Promotion Management. Ed. John A. Quelch. Englewood Cliffs, NJ: Prentice Hall, 1-30.

- Scott A. Neslin, and L. B. Olson. 1987. "Opportunities and Risks of Durable Goods Promotion." Sloan Management Review (Winter): 27-38.

Rossiter, John R. and Larry Percy. 1997. Advertising, Communications, and Promotion Management. New York: McGraw-Hill.

Scheer, Lisa K. and Louis W. Stern. 1992. "The Effect of Influence Type and Performance Outcome on Attitude Toward the Influencer." Journal of Marketing Research 29 (February): 128-142.

Schiller, Zachary. 1993. "Procter \& Gamble Hits Back." Business Week, July 19 , pp. $20+$.

Sinnott, J. William. 1995. "The Case for Co-Marketing: Co-Marketing as a New Form of Manufacturer-Grocery Retailer Relations." Food \& Beverage Marketing 14 (May): 32+.

Sirgy, Joseph M. 1998. Integrated Marketing Communications. Englewood Cliffs, NJ: Prentice Hall.

Speer, Tibbett. 1994. "Do Low Prices Bore Shoppers?” American Demographics (January): 11-15.

Tenser, James. 1996. "A.C. Nielsen Trade Survey Shows Size Does Matter; Trade Promotion Spending." Supermarket News 46 (June 3): S6.

Thibaut, John W. and Harold H. Kelley. 1959. The Social Psychology of Groups. New York: John Wiley.

Van Waterschoot, Walter and Christophe Van den Bulte. 1992. "The 4P Classification of the Marketing Mix Revisited." Journal of Marketing 56 (October): 83-93.
Walters, Rockney C. 1989. "An Empirical Investigation Into Retailer Response to Manufacturer Trade Promotions.” Journal of Retailing 65 (Summer): 253-272.

1991. "Assessing the Impact of Retail Price Promotions on Product Substitution, Complementary Purchase, and Interstore Sales Displacement." Journal of Marketing 55 (April): 17-28.

Williamson, Oliver E. 1989. "Transaction Cost Economics." in Handbook of Industrial Organization. Vol 1. Eds. R. Schmalensee and R. D. Willig. New York: North-Holland, 135-182.

. 1996. "Economics and Organization: A Primer." California Management Review 38 (Winter): 131-146.

Zerrillo, Philip and Dawn Iacobucci. 1995. "Trade Promotions: A Call for a More Rational Approach.” Business Horizons 38 (July-August): 69-76.

\section{ABOUT THE AUTHORS}

Jack J. Kasulis is an associate professor of marketing at the University of Oklahoma. He obtained his Ph.D. in marketing from Northwestern University in Evanston, Illinois, and has research interests in marketing channels, retailing, and consumer behavior. His articles have appeared in such journals as the Journal of Consumer Research, Journal of the Academy of Marketing Science, European Journal of Marketing, Journal of Business Research, Journal of Advertising Research, and various other journals and proceedings.

Fred W. Morgan is the Ashland Professor of Marketing at the University of Kentucky. He obtained his Ph.D. in marketing from Michigan State University in East Lansing and has research interests in legal issues in marketing, sales management, and marketing channels. His articles have appeared in such journals as the Journal of Marketing, Journal of Marketing and Public Policy, Journal of the Academy of Marketing Science, Journal of Marketing Channels, and various other journals and proceedings.

David E. Griffith is an associate professor and the Harvey Jones Chair of Marketing at Ouachita Baptist University. He obtained his Ph.D. in marketing from the University of Texas in Austin and has research interests in marketing channels, marketing strategy, and ethics. His research has appeared in Marketing Letters, Journal of the Academy of Marketing Science, Journal of Marketing Channels, and various other journals and proceedings.

James M. Kenderdine is an associate professor and director of the Distribution Research Program at the University of Oklahoma. He obtained his D.B.A. from Indiana University in Bloomington. His research interests are in wholesaling, retailing, and marketing channels. His publications have included The Changing Economics of Wholesaling: A North American Chart Book, Wholesaling in Transition: An Executive Chart Book, and articles in various journals and proceedings. 